\title{
Improvement of nutritional quality of local dishes and their acceptance by children of different ages
}

\author{
Melhoria de pratos típicos: qualidade \\ nutricional e sua aceitação por \\ crianças de várias idades
}

\author{
María Elena Calderón MARTíNEZ1 (D) 0000-0001-7090-6068 \\ Oswaldo Rey Taboada GAYTÁN1 1 iD 0000-0003-2190-9849 \\ Pedro Antonio LÓPEZ1 (iD) 0000-0001-6620-4549

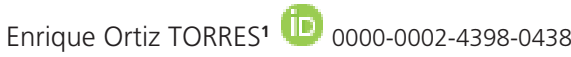

A B S T R A C T

\section{Objective}

Food insecurity and child malnutrition are central topics in many food programs around the world; however, these indices do not diminish. The creation of strategies is necessary to increase the effectiveness of nutritional improvement programs. The objective of this research was to improve the nutritional quality of three local dishes included in the regular diet of the population by adding amaranth and to evaluate their acceptance by children from three communities in Tochimilco, Puebla, Mexico.

\section{Methods}

The study was carried out in three communities of "Tochimilco", Puebla, Mexico, in order to evaluate three local dishes: banana smoothie, beans and corn tortillas, which were chosen by mothers of the region in participative workshops on preparation of local dishes enriched with amaranth. Two sensory tests were applied: pairedcomparison and hedonic scale to 208 and 210 children of preschool and scholar age, respectively.

\footnotetext{
1 Colegio de Postgraduados, Programa de Estrategias para el Desarrollo Agrícola Regional. Campus Puebla, Boulevard Forjadores de Puebla, 205, Santiago Momoxpan, 72760, San Pedro Cholula, Puebla, Mexico. Correspondência para/Correspondence to: ORT GAYTÁN. E-mail: <toswaldo@colpos.mx>.

Article based on the dissertation by MEC MARTÍNEZ entitled "Proceso participativo para incrementar la aceptación de estrategias de desarrollo nutricional: el caso de platillos locales enriquecidos con amaranto en Tochimilco, Puebla". Colegio de Postgraduados; 2016.
}

Como citar este artigo/How to cite this article

Martínez MEC, Gaytán ORT, López PA, Torres EO. Improvement of local dishes' nutritional quality and their acceptance by children of different ages. Rev Nutr. 2018;31(6):603-15. http://dx.doi.org/10.1590/1678-98652018000600009 


\section{Results}

It was found that consumers showed similar preference for banana smoothie and beans enriched with amaranth compared to non-enriched dishes; while the amaranth enriched tortilla gained more preference in the different statistical tests and it was the dish with higher content of amino acids. Sensory attributes were similarly assessed and there were no significant differences among rural and urban communities and school year.

\section{Conclusion}

Children easily accept the addition of amaranth to the dishes they are accustomed to, as it does not change their food culture. It is possible to improve child nutrition by designing healthier dishes and incorporating them into the daily cooking of those who prepare the food.

Keywords: Amaranthus hypochondriacus L. Child malnutrition. Community participation. Nutritional development strategy. Sensory evaluation.

\section{RE S U M O}

\section{Objetivo}

A insegurança alimentar e a desnutrição infantil são temas centrais de muitos programas alimentares ao redor do mundo; no entanto, esses índices não diminuem. É preciso criar estratégias para aumentar a eficácia dos programas de desenvolvimento nutricional. A presente pesquisa teve como objetivo melhorar a qualidade nutricional de três pratos típicos da dieta normal da população local, adicionando amaranto às comidas típicas e avaliando a aceitação dele por crianças de três comunidades em Tochimilco, Puebla, México.

\section{Métodos}

O estudo foi realizado nas três comunidades para avaliar os três pratos típicos desta mesma região: vitamina de banana, feijão e as tortilhas de milho. Estas comidas foram escolhidas por mães da região em oficinas participativas de preparação de pratos locais enriquecidos com amaranto. Dois testes sensoriais foram aplicados: comparação pareada e escala hedônica para 208 e 210 crianças em idade pré-escolar e escolar, respectivamente.

\section{Resultados}

Verificou-se que os consumidores mostraram uma preferência semelhante pela vitamina de banana e feijão enriquecido com amaranto do que os mesmos não enriquecidos; enquanto a tortilha de milho enriquecida com amaranto ganhou mais preferência nos diferentes testes estatísticos e foi o prato com maior teor de aminoácidos. Os atributos sensoriais foram avaliados da mesma forma e não houve diferenças significativas entre as comunidades rurais e urbanas e as notas escolares.

\section{Conclusão}

As crianças aceitam facilmente a incorporação de amaranto nos pratos típicos da dieta delas, pois não representou nenhuma alteração da sua cultura alimentar. É possivel melhorar a nutrição infantil, criando pratos mais saudáveis e incorporando-os na culinária cotidiana daqueles que preparam a comida.

Palavras-chave: Amaranthus hypochondriacus L. Desnutrição infantil. Avaliação sensorial. Estratégia de desenvolvimento nutricional. Participação comunitária.

\section{NTROD U CTION}

Food Insecurity (FI) occurs when a person or a group of people does not have physical or economical access to nutritious, sufficient and innocuous foods that their meet nutritional needs and preferences for an active and healthy life [1]. It is one of the most serious contemporary worldwide problem [2] and it is the main issue of many social and health problems. Some consequences of $\mathrm{Fl}$ are psychological stress, monotonous diet, high energy density food intake and cycles of restriction and binging [3]. These behaviors increase the risk of malnutrition (from malnutrition to obesity) and some infectious diseases [4].

Important steps are being taken around the world to reduce this problem; regional, 
national and international programs are being implemented, as well as studies aimed at monitoring the problem and proposing strategies to reduce the $\mathrm{Fl}$ indices and its consequences [3-7]. Many countries have proposals to fight the causes and consequences of food insecurity; for example, unconditional cash transfers [8], nutrientdense food enriched with micronutrients [9] or grains of amaranth or sorghum [10], own food production through agricultural activity, government social grants and interest money lending, and food from shops [11].

Mexico is a fertile field for strategies against $\mathrm{Fl}$, since the severity of $\mathrm{Fl}$ in the country is increased by many factors such as poverty, marginalization, indigenous languages, average household size, existence of extended households, educational level of the household heads, monthly income and variety of foods in the family diet $[6,7,12]$. Likewise, rural areas are at a high risk because a higher incidence and level (moderate to severe) of $\mathrm{Fl}$ is present $[6,7,13]$. In 2012, Encuesta Nacional de Salud y Nutrición (ENSANUT) [14] reported that $80 \%$ of the households in the rural stratum in Mexico were classified at some level of $\mathrm{Fl}$, compared to $67 \%$ in the urban area. Children under the age of 12 are the most vulnerable group; in fact, the degree of food insecurity is directly related to the degree of malnutrition in Mexican children as households with moderate food insecurity have a higher prevalence of low height and emaciation [12].

The main initiatives proposed by the Mexican federal government are the Crusade Against Hunger [15], the Human Development Opportunities Program (HDOP), now called "Prospera", the Food Support Program (FSP), the Social Milk Supply Program (SMSP) and the Rural Supply Program (RSP) [16]. However, FI and its serious consequences still prevail [14]. The low effectiveness of these programs is due to the poor implementation of strategies (lack of regionalization, modification in food culture and poor professional supervision) and the influence of paternalism, which causes a decrease in community participation and empowerment of the population [17]. That is why well-designed, implemented and supervised strategies are required to reduce the impact of food insecurity, to ensure adequate nutrition to the most vulnerable, that is, to the children in the countryside.

The objective of this research was to improve the nutritional quality of three local dishes included in the regular diet of the population by adding amaranth and to evaluate its acceptance among children from three communities in Tochimilco, Puebla, Mexico. The central element of this study is to improve local dishes and food resources. The strategy of adding amaranth to traditional culinary preparations is suggested as a measure to improve the nutritional quality of these preparations in regions where food insecurity is recurrent.

\section{METHODS}

\section{Location and characteristics of the region of study}

The study was carried out in the municipality of Tochimilco, in the state of Puebla, Mexico, located in the center-west of the state of Puebla, between the parallels $18^{\circ} 50^{\prime}$ and $19^{\circ} 02^{\prime} \mathrm{NL}$ and the meridians $97^{\circ} 18^{\prime}$ and $97^{\circ} 27^{\prime} \mathrm{WL}$ [18]. This municipality has a total area of $233.45 \mathrm{~km}^{2}$ and 17,025 inhabitants. The main economic activity is agriculture [19].

The municipality consists of 24 localities, of which three are urban and 21 are rural. The study was carried out in three localities, two are classified as rural and one as urban: Santiago Tochimizolco with 747 inhabitants, San Miguel Tecuanipa with 1,378 inhabitants and La Magdalena Yancuitlalpan with 2,201 inhabitants. The three localities have a high level of marginalization and medium social underdevelopment [20]. 


\section{Materials}

Information was collected during the months of August to October 2015 using sensorial analysis tests. Three previously selected dishes were evaluated: beans, banana smoothie and handmade corn tortilla. The selection was based on the results of two previous studies: the first study conducted a community diagnosis to determine which were the most highly consumed foods by the study population and the typical food of the region's culture [21]; the second one were amaranth-enriched food preparation workshops (Amaranthus hypochondriacus L.) during which the participating housewives proposed which dishes would be enriched [22]. The results of both studies converged in the choice of the dishes to evaluate.

The preparation of the local dishes was carried out by a native and resident lady of the community of La Magdalena Yancuitlalpan, Tochimilco, familiar with local food customs; there were only small differences in the dishes enriched with amaranth. The concentration of popped amaranth seed in the dishes were as follows: $2.22 \%$ in beans, $1.78 \%$ in the banana smoothie and $2.11 \%$ of amaranth flour in the corn tortilla. We selected the amaranth crop due to the high nutritional quality of the grain; it has high-quality protein, carbohydrates, lipids and several minerals and vitamins [23]. Since most of the population grow the grain, it is a widely available local resource [21]. In fact, Tochimilco occupies the second place in the production of amaranth at national level. In 2015, the production of the municipality was $1,111 \mathrm{t}$ and its average yield was 1.01tha-1 [24].

Two tests were applied to obtain the information. In the first one, the pairedcomparison test [25], each child in different school years was given two samples (A first, $B$ second) of one dish, one sample without amaranth and one sample with amaranth, to measure the taste preferences of the dishes. In the second test, the hedonic scale test [25], three dishes enriched with amaranth were used to evaluate acceptability using a 5-point facial hedonic scale with the categories: (1) "I hated it"; (2) "I did not like it"; (3) "Indifferent"; (4) "I liked"; and (5) "I loved it". Four sensory attributes were evaluated in the following order: appearance, odor, consistency or texture and taste. In both tests, evaluation cards were given to each child where they recorded their observations for later analysis.

\section{Population and study sample size}

In this study we used two different samples. For the paired preference test, a total of 208 preschool and school children from kindergarten and elementary school participated. The participants were 51 children from the community of Santiago Tochimizolco, 74 children from San Miguel Tecuanipa and 83 children from La Magdalena Yancuitlalpan. Children participation was distributed as follows: there were 7 children in $1^{\text {st }}$ kindergarten, 28 in $2^{\text {nd }}$ grade, 39 in $3^{\text {rd }}$ grade, 24 in $1^{\text {st }}$ elementary, 24 in $2^{\text {nd }}$ elementary, 15 in $3^{\text {rd }}$ elementary, 23 in $4^{\text {th }}$ elementary, 24 in $5^{\text {th }}$ elementary, and 24 in $6^{\text {th }}$ grade.

A total of 210 children participated in the hedonic scale test: of which 51 children were from Santiago Tochimizolco, 75 children from San Miguel Tecuanipa, and 84 children from La Magdalena Yancuitlalpan. Considering school year, there were 7 children in $1^{\text {st }}$ kindergarten, 30 in $2^{\text {nd }}$ grade, 38 in $3^{\text {rd }}$ grade, 22 in $1^{\text {st }}$ elementary, 26 in $2^{\text {nd }}$ elementary, 15 in $3^{\text {rd }}$ elementary, 24 in $4^{\text {th }}$ elementary, 24 in $5^{\text {th }}$ elementary and 24 in $6^{\text {th }}$ elementary.

The sample size was not calculated as the children were chosen for their degree of willingness to participate; the number of children per school was proportional to school enrollment, and the school grades among all children were equal.

\section{Analysis of the amino acid profile}

The amino acid profile contained in the three dishes with and without amaranth 
was carried out in the Laboratory of chemical analysis for foods of the Department of Animal Nutrition and Biochemistry of the Universidade Nacional Autónoma do México (UNAM, National Autonomous University of Mexico). The determination of the amino acid content was carried out in duplicate and the technique used was the AccQ-Tag amino acid analysis using HPLC, Waters [26].

\section{Statistical analysis}

With the information obtained from the 418 evaluation ballots, descriptive statistics tools in Microsoft Excel were used to analyze the data (Microsoft Corp., Redmond, Washington DC, United States). Likewise, multivariate statistical techniques were applied. In the case of the paired preference test, a two-tailed binomial test was applied first, since the preference could not have been known before the study was carried out [27]; subsequently, the nonparametric one-way variance analysis using the Kruskal-Wallis test was used to evaluate the effect of the communities and school grades. For the analysis of the hedonic scale test, the multivariate correspondence analysis and TukeyKramer means test for the variables 'community', 'school grade' and 'sensory attribute' were used. The significance level was $p \leq 0.05$. The Statistical Analysis System software, version 9.1, (SAS Institute Inc., Cary, North Carolina, United States) [27] was used for all the data.

\section{RES ULT S}

The amino acid profile of each chosen dish was obtained; results are presented in Table 1. Few increases of amino acids were observed in the enriched beans and smoothie, compared to the non-enriched sample, even depreciation in some amino acids was shown, probably because the amount of amaranth was not relevant. However, increases in histidine and phenylalanine in the banana smoothie were significant, $127 \%$ and $52 \%$, respectively. In the case of beans, the maximum increase in isoleucine was $32 \%$.

Corn tortilla with and without amaranth yielded excellent results; although some amino acids were reduced, other contents were remarkable increased. For example, glutamic acid content increased 11-fold, histidine increased by almost 4-fold, methionine increased approximately $700 \%$, and arginine and isoleucine practically doubled their content.

Two tests were performed for the sensorial analysis of the three dishes; results are shown in Table 2. The paired preference test was applied between a dish enriched with amaranth and a dish prepared in the traditional way. According to the results of the two-tailed binomial test, the children's preference for dishes without amaranth and those enriched with it were similar, although in the case of the smoothie there was a slight preference for the food that did not contain amaranth. On the other hand, amaranth-enriched corn tortilla had a higher percentage of preference $(58 \%)$ than the non-enriched one.

As a result of the non-parametric analysis of variance, in the Kruskal-Wallis test, we found that there were no significant differences between school year and their preference per dish (enriched or non-enriched); but significant differences were found for the "community" factor in the preference for amaranth-enriched corn tortilla. In this case, the urban community preferred amaranth-enriched tortillas.

Likewise, an analysis of correspondences was carried out between community, school year and dish. In the case of beans, no significant statistical differences were found among children who chose beans without amaranth and those who chose beans enriched with amaranth. Schooling did not influence the decision of the children, although it was observed that the children from San Miguel Tecuanipa and those in the third grade were the most frequent groups 
Table 1. Composition of essential amino acids ( $\mathrm{g} / 100 \mathrm{~g}$ of true protein) in samples of bean, banana smoothies and corn tortilla with and without amaranth evaluated by children of different ages in three localities of Tochimilco, Puebla, Mexico, 2015.

\begin{tabular}{|c|c|c|c|c|c|c|c|c|c|}
\hline \multirow[b]{2}{*}{ AA } & \multicolumn{2}{|c|}{ Beans } & \multirow{2}{*}{$\begin{array}{l}\text { Dif } \\
(\%)\end{array}$} & \multicolumn{2}{|c|}{ Smoothie } & \multirow{2}{*}{$\begin{array}{l}\text { Dif } \\
(\%)\end{array}$} & \multicolumn{2}{|c|}{ Tortilla } & \multirow{2}{*}{$\begin{array}{l}\text { Dif } \\
(\%)\end{array}$} \\
\hline & (E) & (NE) & & (E) & (NE) & & (E) & (NE) & \\
\hline Asp & 11.749 & 12.316 & -5 & 6.184 & 5.227 & 18 & 5.122 & 5.496 & -7 \\
\hline Ser & 7.545 & 7.596 & -1 & 4.043 & 3.990 & 1 & 3.186 & 3.475 & -8 \\
\hline Glu & 15.224 & 15.043 & 1 & 14.895 & 40.915 & -64 & 8.640 & 0.715 & 1108 \\
\hline Gly & 4.563 & 4.167 & 10 & 1.981 & 1.748 & 13 & 0.350 & 5.320 & -93 \\
\hline His & 5.188 & 5.574 & -7 & 2.634 & 1.162 & 127 & 20.580 & 6.103 & 237 \\
\hline $\mathrm{NH} 3$ & 1.002 & 1.320 & -24 & 1.114 & 1.527 & -27 & 0.767 & 2.552 & -70 \\
\hline Arg & 6.761 & 6.690 & 1 & 2.764 & 2.184 & 27 & 7.716 & 3.428 & 125 \\
\hline Thr & 5.426 & 5.302 & 2 & 3.127 & 3.108 & 1 & 3.227 & 2.768 & 17 \\
\hline Ala & 4.406 & 4.374 & 1 & 2.827 & 2.303 & 23 & 4.904 & 6.732 & -27 \\
\hline Pro & 4.308 & 4.196 & 3 & 6.764 & 6.596 & 3 & 5.633 & 7.783 & -28 \\
\hline Cys & 0.494 & 0.543 & -9 & 0.208 & 0.203 & 3 & 0.365 & 0.655 & -44 \\
\hline Tyr & 3.738 & 3.450 & 8 & 2.413 & 3.584 & -33 & 4.593 & 3.428 & 34 \\
\hline Val & 3.368 & 2.896 & 16 & 2.134 & 3.134 & -32 & 1.920 & 2.884 & -33 \\
\hline Met & 0.654 & 0.539 & 21 & 1.325 & 1.682 & -21 & 9.647 & 1.209 & 698 \\
\hline Lys & 6.148 & 5.928 & 4 & 5.293 & 5.253 & 1 & 2.008 & 1.820 & 10 \\
\hline lle & 3.336 & 2.521 & 32 & 1.786 & 2.104 & -15 & 3.352 & 1.910 & 76 \\
\hline Leu & 6.714 & 7.160 & -6 & 5.853 & 6.643 & -12 & 8.740 & 10.693 & -18 \\
\hline Nleu & 1.412 & 1.640 & -14 & 1.410 & 1.779 & -21 & 2.819 & 3.536 & -20 \\
\hline Phe & 6.199 & 6.580 & -6 & 5.098 & 3.346 & 52 & 3.423 & 3.809 & -10 \\
\hline
\end{tabular}

Note: AA: Amino acid; E: Enriched with amaranth; NE: Not enriched with amaranth; Dif: Difference.

Asp: Aspartic Acid; Ser: Serine; Glu: Glutamic Acid; Gly: Glycine; His: Histidine; NH3: Ammonia; Arg: Arginine; Thr: Threonine; Ala: Alanine; Pro: Proline; Cys: Cysteine; Tyr: Tyrosine; Val: Valine; Met: Methionine; Lys: Lysine; Ile: Isoleucine; Leu: Leucine; NLeu: Norleucine; Phe: Phenylalanine.

Table 2. Statistical two-tailed binomial test and Kruskal Wallis test to determine the preference of local dishes enriched with amaranth by children of different ages in three localities of Tochimilco, Puebla, Mexico, 2015.

\begin{tabular}{|c|c|c|c|c|c|c|c|c|c|}
\hline \multirow{4}{*}{ VF } & \multicolumn{9}{|c|}{ Local dishes } \\
\hline & \multicolumn{3}{|c|}{ Beans } & \multicolumn{3}{|c|}{ Smoothie } & \multicolumn{3}{|c|}{ Tortilla } \\
\hline & \multicolumn{2}{|c|}{ B } & \multirow{2}{*}{$\frac{\mathrm{KW}}{\mathrm{Pr}>\mathrm{ChiSq}}$} & \multicolumn{2}{|c|}{ B } & \multirow{2}{*}{$\frac{\mathrm{KW}}{\mathrm{Pr}>\mathrm{ChiSq}}$} & \multicolumn{2}{|c|}{ B } & \multirow{2}{*}{$\frac{\mathrm{KW}}{\mathrm{Pr}>\mathrm{ChiSq}}$} \\
\hline & $\operatorname{Pr}>Z$ & $\%(E)$ & & $\operatorname{Pr}>Z$ & $\%(E)$ & & $\operatorname{Pr}>Z$ & $\%(E)$ & \\
\hline C & 0.7218 & 47.9 & 0.8716 & 0.0523 & 38.2 & 0.3694 & 0.1854 & 57.9 & 0.0141 \\
\hline SG & 0.7218 & 47.9 & 0.3278 & 0.0523 & 38.2 & 0.1731 & 0.1854 & 57.9 & 0.2992 \\
\hline
\end{tabular}

Note: VF: Variation factor; B: Two-tailed binomial test; KW: Kruskal Wallis test; C: Community; SG: School year. \% (E): Percentage of the sample who chose the enriched dish.

that chose beans enriched with amaranth. In the case of the smoothie, there was no significant numerical difference among the decision taken by the children in all communities and school year/educational stage. Graphically, the children from La Magdalena Yancuitlalpan and students in $2^{\text {nd }}$ and $6^{\text {th }}$ grades had a greater preference for enriched food. Corn tortilla did show a significant difference, particularly when the Wilcoxon test was carried out between communities. La 
Magdalena Yancuitlalpan was the community that most frequently chose amaranth-enriched tortilla, while the children who most frequently chose enriched tortilla were in the $2^{\text {nd }}$ and $3^{\text {rd }}$ kindergarten grades and $6^{\text {th }}$ grade (Figure 1).

As part of the analysis of the information collected, the scaling test with hedonic facial scale was performed using descriptive statistics and multivariate analysis. The children evaluated sensory attributes of the three dishes enriched with amaranth. The box plots (Figure 2) show the values given by children to each sensory attribute and dish. In general, the ratings were high: the lowest was "Indifferent", except for the smoothie flavor that was rated "I liked it". That is, $25 \%$ of the population assigned values between "Indifferent" and "I liked it" to the "appearance", "smell", "consistency/texture" and "flavor" of the dishes, while the remaining $75 \%$ rated between "I liked it" and "I loved it". Visually, the average of the tortilla's flavor was slightly higher than the rest of the evaluations.

In the results of the analysis of multivariate and univariate variance (in general and attribute by attribute) no significant differences were found between the communities ( $p>0.05)$. Likewise, the same analysis was performed for the factor "school year". In this case, significant differences $(p \leq 0.05)$ were found taking into account the four sensorial attributes and individual analysis of each attribute, except for flavor. In the analysis of multivariate variance for

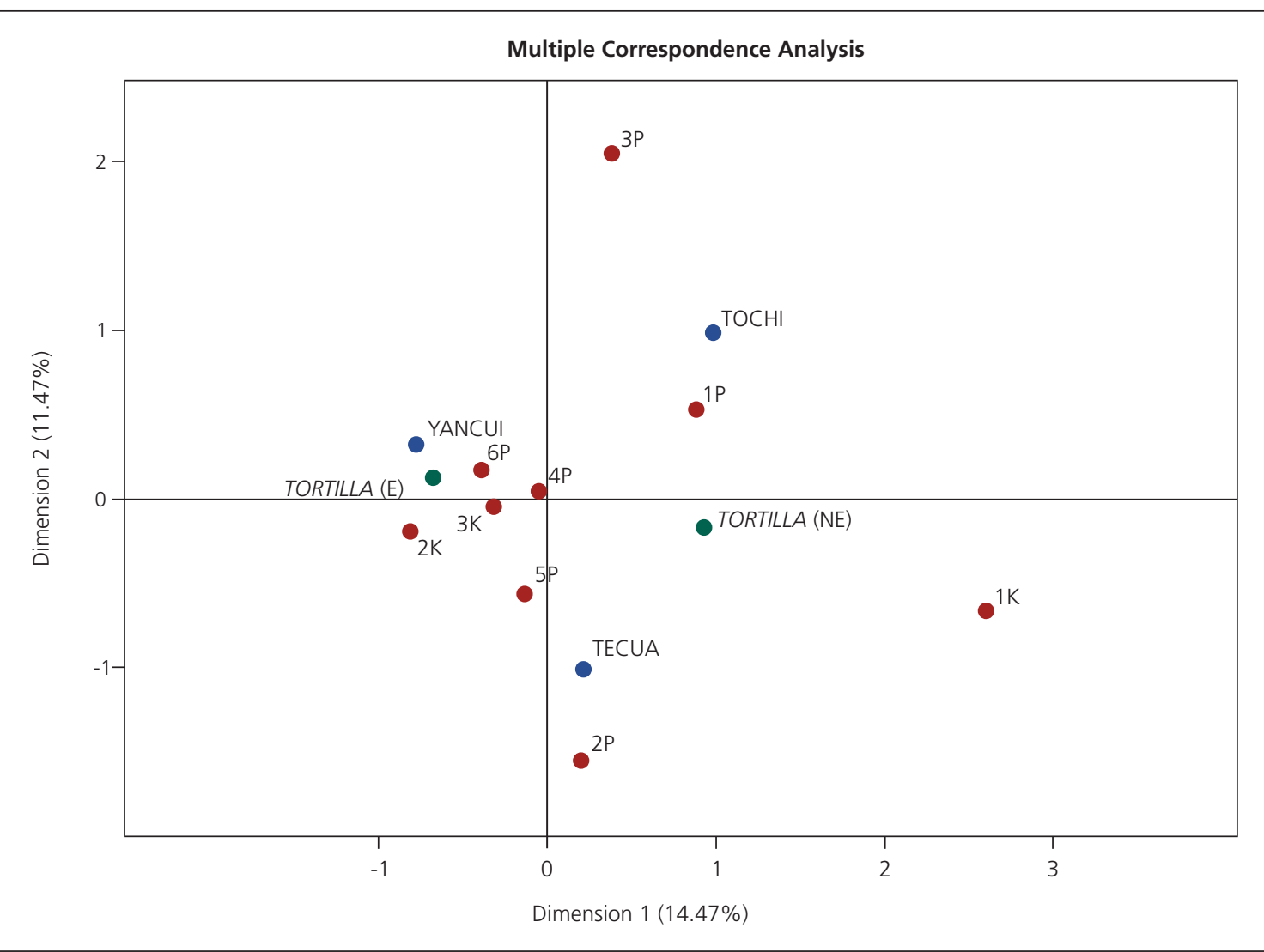

Figure 1. Correspondence analysis for community and school year variables for tortilla enriched and not enriched with amaranth in three localities of Tochimilco, Puebla, Mexico, 2015.

Note: TORTILLA (E): Enriched with amaranth tortilla; TORTILLA (NE): Not enriched with amaranth tortilla; YANCUI: La Magdalena Yancuitlalpan locality; TOCHI: Santiago Tochimizolco locality; TECUA: San Miguel Tecuanipa locality; K: kindergarten school; P: elementary school. 

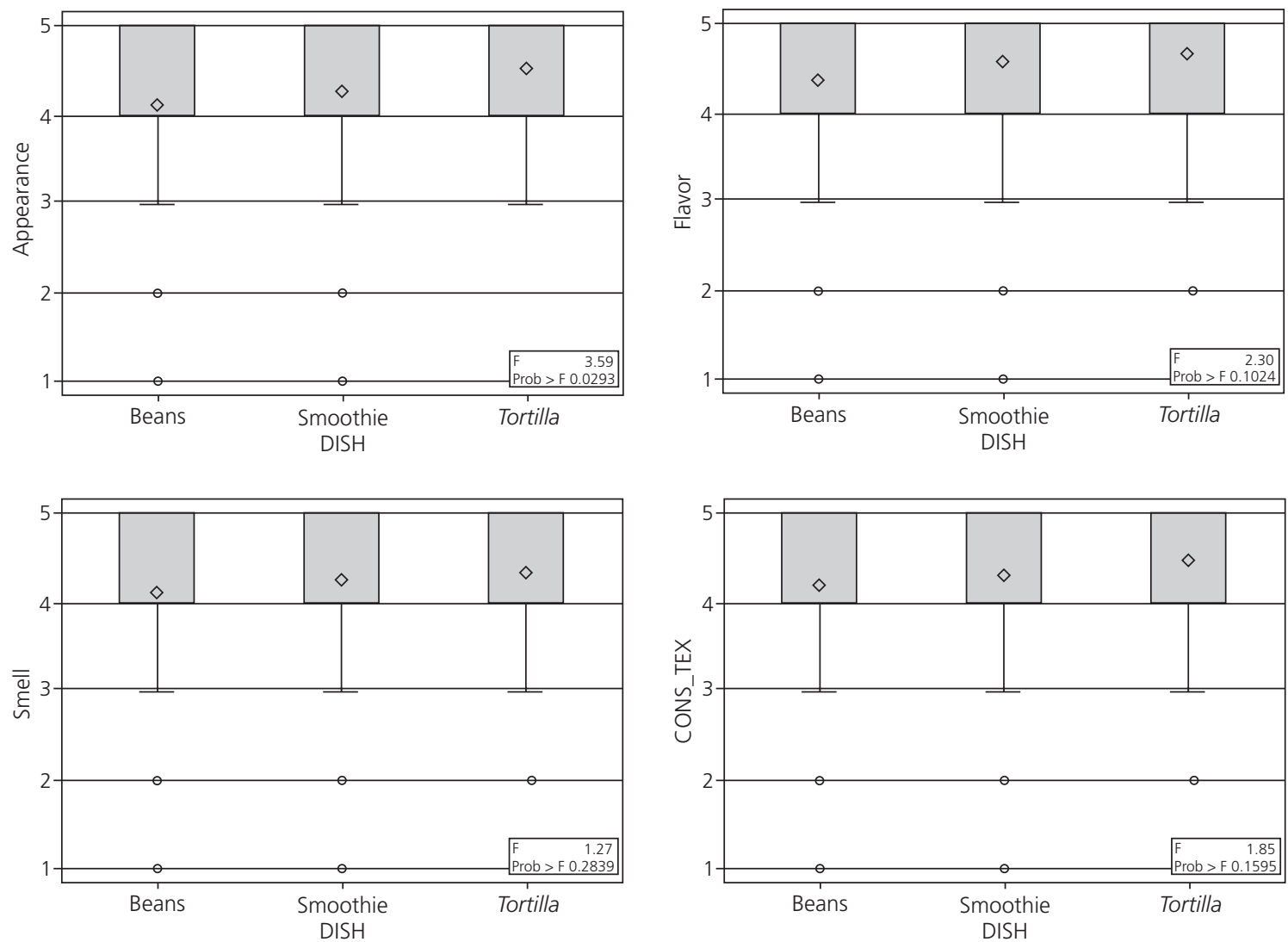

Figure 2. Assigned values in the scaling test to the sensory attributes of the dishes enriched with amaranth according to children of different ages in three localities of Tochimilco, Puebla, Mexico, 2015.

Note: 5: "I loved it"; 4: "I liked"; 3: "Indifferent"; 2: "I did not like it"; 1: "I hated it".

dish in relation to the four sensorial attributes, there was no statistical significance $(p>0.05)$, so no preference was observed for a particular dish; however, there was a significant difference only for appearance in the univariate analysis.

\section{DISCUSSION}

In the amino acid profile of the dishes, different quantities than those described in previous investigations were shown. Juan et al. [28] mention that beans have high values of sulfured amino acids (methionine + cysteine), contrary to the results of this study; however, they match the results presented by Guzmán et al. [29], who reported that lysine, phenylalanine and tyrosine are found in high quantities and methionine and cysteine are deficient. The probable explanation for the results in the amino acid profile of beans may be the natural content of proteins in these legumes; because beans have high quantity of amino acids on their own, no significant increases are observed when enriched with amaranth.

The most relevant increase in banana smoothie enriched with amaranth was for histidine: wich is an essential amino acid for children; involved in the immune system, binds to the prosthetic heme groups of hemoglobin, prevents apoptosis, and promotes cell growth and antibody production [30,31]. Milk is a regular food in families who have young children [21]. If milk were to be added with banana and amaranth, it could increase the intake of 
histidine in the children and would improve its response to antigens.

Although banana smoothie is a good option, amaranth-enriched corn tortilla is the ideal option to enrich the diet of the child population in Tochimilco, Puebla, because corn tortilla is consumed daily [21] and it is an "element that identifies Mexican food" as well as a part of the culinary heritage [32].

The enriched tortilla was the most preferred dish among the children in the degustation tests and greater increases in the concentration of some amino acids were obtained. Amaranth and maize complement each other in the concentration of some amino acids [23,33], which increases the biological value of the protein. Histidine, methionine, isoleucine, glutamic acid and arginine increased considerably when adding amaranth flour; the first three are essential amino acids. In contrast, Amaya [34] found low values of histidine, methionine+cysteine and threonine in amaranth flour. The literature also describes methionine and lysine as amino acids present in amaranth [23,35], but lysine did not increase significantly. On the other hand, Juan et al. [28] concluded that the species $A$. hypochondriacus is deficient in tyrosine, phenylalanine, lysine and histidine; the first three agree with our study, but in the case of histidine, high quantities were found; likewise, a higher content of methionine was present than the one reported.

In the sensory tests, the population gave high scores for the dishes evaluated; these results indicate that preschoolers and schoolchildren can accept foods rich in amaranth in their regular diet. We can point to the phenomenon of "flavor-flavor learning" [36], since a new ingredient was added to dishes widely accepted by children. Therefore, the nutritional improvement strategy can be more efficient when it includes base dishes of the family nourishment. Osorio et al. [37] confirm this when mentioning that the alimentary conduct is conditioned by different factors and the most important is experiencing a variety of flavors, particularly during the first years of life; that is to say, the constant consumption of food improves the disposition to eat it later in life, since its flavor is familiar [38], and contributes to educate taste; other influential factors are the mother's culture [39] and the psychological and social components of the child [37]. It was observed in the applied sensory tests that the stage of growth (preschool and school), age of the population and belonging to any of the communities do not significantly determine the preference of the local dishes evaluated.

Although a sample design was not performed, the probability of bias was reduced due to the high representativeness of the study population, since the children participating in the study lived in communities with similar characteristics [21]. Likewise, Bergel et al. [40] mentioned that the perception and representations about family feeding practices is similar in rural, peri-urban and urban areas; for example, families of the three areas decide their meals according to the criterion of "good nutrition"; in addition, the consumption of food is related to the adjustment of habits and tastes, more than to other limitations.

The children showed willingness to participate and their participation was voluntary; thus, probably their responses correspond to their tastes and preferences in terms of food consumption as part of their regular diet.

The previous selection of the three main local dishes, with help of the mothers, may have contributed to the high acceptability of the dishes with amaranth, since they know the preferences of the children, and they are accustomed to the traditional foods of the region [39]. Therefore, knowing the preferences and the usual dishes of the population [21], added to the easy access to amaranth crops, increased the probability of adding healthier amaranth-enriched dishes to the regular diet of children.

Amaranth-enriched corn tortilla is an excellent way to improve nutrition in Mexico due to the children's acceptability, high values 
in the scaling test and because their sensory attributes changed minimally. There was only a significant difference for appearance in the univariate analysis, which indicates that the appearance of food influences the degree of preference, and it is in agreement with the study carried out by García et al. [41], who showed that "for children the sensorial attributes of appearance and color are imperative and of high priority for the preference and approval of any food product that focuses on the children population". The appearance of local dishes enriched with amaranth must be a priority, perhaps using amaranth flour instead of whole grain, with the aim of obtaining an appearance that pleases most children.

It should be mentioned that the tortilla was prepared in a completely traditional way in the studied communities and it is a national food that is consumed on a daily basis and in high quantities, so it is representative of Mexican food culture and life [32]. In fact, it has been the object of many studies where it is used as a vehicle for beneficial substances for the human being; various foods have been added to this food (banana, cassava etc.) or substances, such as amino acids, with the aim of increasing its nutritional value $[9,42]$ and even denominate it as functional food. That is why it can be used in rural regions that are also main producing areas of amaranth, since its addition to the tortilla can be constant until it becomes a regular food in their diet without changing the identity and food culture; however, education must be provided to raise the awareness of those responsible for feeding the family.

Various food products have been made based on amaranth [10], but most of them have high calorie density and high content of simple carbohydrates and lipids; this composition diminishes the nutritional quality of the food with amaranth. In this study, the evaluated enriched dishes provide a better balance of macronutrients, which represents greater health and nutrition benefits to the children, because they are regular foods in the habitual diet of the inhabitants of the region and locally available [21], increasing chances of acceptance among children at risk or with malnutrition. A minimal modification (addition of amaranth) improves protein quality, amino acid content, carbohydrates and micronutrients $[23,43]$ and these can improve the nutritional status of children [44]. Furthermore, they are low-cost foods, which contributes to decrease food insecurity of families in rural localities, since prevalence was $84 \%$ in the families of Puebla in 2012 [14].

\section{CONCLUSIONS}

Children easily accept dishes to which they are accustomed to in their regular diet, even if they are nutritionally enriched, so they can be a vehicle for increased protein intake. The population can add amaranth, a local resource, to their diet as long as they do not change their food culture and know how to prepare healthier dishes. Further studies should be conducted to observe the addition of amaranth to regular dishes and the effects on the children's health.

\section{CONTRIBUTORS}

MEC MARTÍNEZ participated in the concept and design, field work, analysis and interpretation of data, and the writing of the article. ORT GAYTÁN contributed to the concept and design, article revision, and approval of the final version of the article. PA LÓPEZ analyzed, interpreted data and reviewed the article. EO TORRES contributed to the concept and design, article revision.

\section{A CKNOWLEDGMENTS}

We thank Mrs. Laura Carranza of "La Magdalena Yancuitlalpan" for the preparation of the sample dishes, the children for giving their sincere opinion, and the local authorities for their support during the investigation. 


\section{REFERENCES}

1. Jones AD, Ngure FM, Pelto G, Young SL. What are we assessing when we measure food security? A compendium and review of current metrics. Adv Nutr. 2013;4(5):481-505. http://dx.doi.org/10.39 45/an.113.004119

2. Godfray HCJ, Beddington JR, Crute IR, Haddad L, Lawrence D, Muir JF, et al. Food security: The challenge of feeding 9 billion people. Science. 2010;327(812):812-18. http://dx.doi.org/10.1126/ science. 1185383

3. Hernández ME, Pérez SD, Ortiz-Hernández S. Consecuencias alimentarias y nutricionales de la inseguridad alimentaria: la perspectiva de madres solteras. Rev Chil Nutr. 2013;40(4):351-6. http:// dx.doi.org/10.4067/S0717-75182013000400004

4. Hackett M, Melgar-Quiñonez $H$, Cecilia AM. Household food insecurity associated with stunting and underweight among preschool children in Antioquia, Colombia. Rev Panam Salud Pública. 2009;25(6):506-10. http://dx.doi.org/10. 1590/S1020-49892009000600006

5. Martínez-Rodríguez JC, García-Chong NR, TrujilloOlivera LE, Noriero-Escalante L. Inseguridad alimentaria y vulnerabilidad social en Chiapas: el rostro de la pobreza. Nutrición Hospitalaria. 2015 [acceso 2016 feb 17];31(1):475-81. Disponible en: http://www.redalyc.org/articulo.oa?id=3092 32878053

6. Vega-Macedo $M$, Shamah-Levy $T$, PeinadorRoldán R, Méndez-Gómez HI, Melgar-Quiñónez $\mathrm{H}$. Inseguridad alimentaria y variedad de la alimentación en hogares mexicanos con niños menores de cinco años. Salud Pública Méx. 2014 [acceso 2016 ene 21];56(Suppl.1):21-30. Disponible en: http://www.redalyc.org/articulo. oa?id=10632374005

7. Rosso MA, Wicky Ml, Nessier MC, Meyer R. Inseguridad alimentaria en la ciudad de Santa Fe: percepción de los ciudadanos. Salud Colectiva. 2015 [acceso 2016 feb 19];11(2):235-45. Disponible en: http://www.scielo.org.ar/ scielo. php?script=sci_arttext\&pid=S18 5182652015000 200007\&lng=es\&nrm=iso

8. Grellety E, Babakazo P, Bangana A, Mwamba G, Lezama I, Zagre NM, et al. Effects of unconditional cash transfer son the outcome of treatment for severe acute malnutrition (SAM): A clusterrandomised trial in the Democratic Republic of the Congo. BMC Med. 2017;15(87):1-19. http:// dx.doi.org/10.1186/s12916-017-0848-y

9. Canul R, Betancur ADA, Castellanos RAF, Chel GLA. Tortilla de maíz fortificada con aminoácidos para la alimentación de niños desnutridos en
Yucatán, México. Nutr Clín Diet Hosp. 2012 [acceso 2016 ene 20];32(3):30-5. Disponible en: http://revista.nutricion.org/PDF/TORTILLA.pdf

10. Okoth JK, Ochola SA, Gikonyo NK, Makokha A. Development of a nutrient-dense complementary food using amaranth-sorghum grains. Food Sci Nutr. 2017;5(1):86-93. http://dx.doi.org/10.1002/ fsn3.367

11. Musemwa L, Muchenje V, Mushunje A, Aghdassi F, Zhou L. Household food insecurity in the poorest province of South Africa: Level, causes and coping strategies. Food Sec. 2015;7(3):647-55. http:// dx.doi.org/10.1007/s12571-015-0422-4

12. Shamah-Levy T, Mundo-Rosas V, Rivera-Dommarco JA. La magnitud de la inseguridad alimentaria en México: su relación con el estado de nutrición y con factores socioeconómicos. Salud Pública Méx. 2014 [acceso 2015 sep 12];56(Suppl.1):79-85. Disponible en: http://www.scielo.org.mx/scielo. php?script=sci_arttext\&pid=S0036-363420140 $00700012 \&$ lng =es\&nrm=iso

13. Mundo-Rosas V, Shamah-Levy T, Rivera-Dommarco JA. Epidemiología de la inseguridad alimentaria en México. Salud Pública Méx. 2013 [acceso 2015 oct 1];55(Suppl.2):206-13. Disponible en: http://www.scielo.org. mx/scielo.php?script=sci_ arttext\&pid=S0036-36342013000800018\&lng=e s\&nrm=iso

14. Gutiérrez JP, Rivera-Dommarco J, Shamah-Levy T, Villalpando-Hernández S, Franco A, Cuevas-Nasu I, et al. Encuesta Nacional de Salud y Nutrición 2012: Resultados Nacionales. Cuernavaca: Instituto Nacional de Salud Pública; 2012.

15. De La Cruz JL. La Cruzada Nacional contra el Hambre: perspectivas. 2013 [acceso 2015 oct 1];2:1-11. Disponible en: http://www.fesmex.org/ common/Documentos/Libros/Paper_PP_Cruzada_ Nac_vs_Hambre_delaCruz_Sep2013.pdf

16. Secretaría de Desarrollo Social. Diagnóstico integral de los programas alimentarios de la SEDESOL. 2012 [acceso 2015 nov 13]. Disponible en: https://www.gob.mx/cms/uploads/attachment/ file/31967/Diagnostico_Alimentario_Resumen_ Ejecutivo_1_.pdf

17. Sosa LI, Pierre LC, Guerra CM, Ferrer FL, Rodríguez $\mathrm{SA}$, Bonet GM, et al. Propuesta metodológica para la planificación, implementación y evaluación participativas en Áreas de Salud - Consejos Populares. Rev Cubana Med Gen Integr. 2013 [acceso 2015 ene 22];29(2):173-83. Disponible en: http://scielo.sld.cu/scielo.php?script=sci_arttext\& pid=S0864-21252013000200008\&lng=es\&nrm =iso

18. Secretaría de Desarrollo Social. Atlas de riesgos del municipio de Tochimilco. 2011 [acceso 2015 nov 13]. Disponible en: http://www.normateca. 
sedesol.gob.mx/work/models/SEDESOL/ Resource/2612/Atlas_Estados/21188_TOCHI MILCO/ATLAS\%20DE\%20RIESGO\%20DE \%20 TOCHIMILCO\%202011.pdf

19. Instituto Nacional de Estadística y Geografía. Censo de población y vivienda, 2010: marco geoestadístico municipal. 2010 [acceso 2015 dic 10]. Disponible en: http://www3.inegi.org. $\mathrm{mx} /$ sistemas/biblioteca/ficha.aspx ?upc $=702825$ 292805

20. Secretaría de Desarrollo Social. Catálogos de localidades. 2013 [acceso 2015 jun 25]. Disponible en: http://www.microrregiones.gob. $\mathrm{mx} /$ catloc/LocdeMun.aspx?tipo=clave $\&$ campo= loc\&ent=21\&mun=188

21. Calderón MME, Taboada GOR, Argumedo MA, Ortiz TE, López PA, Jacinto HC. Cultura alimentaria: clave para el diseño de estrategias de mejoramiento nutricional de poblaciones rurales. ASyD. 2017;14(2):303-21. http://dx.doi.org/10. 22231/asyd.v14i2.594

22. Calderón MME. Proceso participativo para incrementar la aceptación de estrategias de desarrollo nutricional: el caso de platillos locales enriquecidos con amaranto en Tochimilco, Puebla [disertación]. México: Colegio de Postgraduados; 2016.

23. Huerta OJA, Barba RAP. Caracterización bioquímica y estructural de las proteínas de reserva de amaranto. In: Espitia R, editor. Amaranto: ciencia y tecnología: México: INIFAP/SINAREFI; 2012.

24. Servicio de Información Agroalimentaria y Pesquera. Cierre de la producción agrícola por estado. 2015 [acceso 2016 nov 4]. Disponible en: http://infosiap.siap.gob.mx/aagricola_siap_gb/ icultivo/index.jsp

25. Ramírez-Navas JS. Análisis sensorial: pruebas orientadas al consumidor. ReCiTelA. 2012 [acceso 2015 oct 1];12(1):82-101. Disponible en: https:// www.researchgate.net/publication/257890512 Analisis_sensorial_pruebas_orientadas_al_ consumidor

26. Kaspar H, Dettmer K, Gronwald W, Oefner PJ. Advances in amino acid analysis. Anal Bioanal Chem. 2009;393(2):445-52. http://dx.doi.org/10. 1007/s00216-008-2421-1

27. Statistical Analysis Software. SAS/STAT, version 9.1. North Carolina: SAS Institute Inc; 2004.

28. Juan R, Pastor J, Alaiz M, Megías C, Vioque J. Caracterización proteica de las semillas de once especies de amaranto. Grasas Aceites. 2007 [acceso 2015 abr 11];58(1):49-55. Disponible en: https://dialnet.unirioja.es/servlet/articulo?codigo= 2272490
29. Guzmán MSH, Acosta GJA, Álvarez-Muñoz MA, García-Delgado S, Loarca-Piña G. Calidad alimentaria y potencial nutracéutico del frijol (Phaseolus vulgaris L.). Agric Téc Méx. 2002 [acceso 2015 Sep 23];28(2):159-73. Disponible en: http://www.redalyc.org/articulo.oa?id=60828206

30. Mckee T, Mckee J. Bioquímica: las bases moleculares para la vida. 4a ed. Ciudad de México: McGraw-Hill; 2009.

31. Gil HA. Tratado de Nutrición: composición y calidad nutritiva de los alimentos. Tomo II. 2a ed. España: Ed. Médica Panamericana; 2010.

32. Calleja PM, Valenzuela MB. La tortilla como identidad culinaria y producto de consumo local. Región Soc. 2016;28(66):161-94. http://dx.doi. org/10.22198/rys.2016.66.a404

33. García Rodríguez JG, Cervantes OF, Ramírez PJG, Aguirre MC, Rodríguez PG, Ochoa F, et al. Determinación de lisina, triptófano, y proteína en germinados de maíz criollo y QPM. Rev Mex Ciênc Agríc. 2017;8(4):877-90. http://dx.doi.org/10.29 312/remexca.v8i4.14

34. Amaya GCA. Efectos de la fortificación y enriquecimiento de tortillas regulares y de maíz de alta calidad proteica en el desarrollo fisiológico, cerebral y desempeño en el aprendizaje de ratas de laboratorio [tese]. San Nicolás de los Garza: Universidad Autónoma de Nuevo León; 2003.

35. Grobelnik-Mlakar S, Turinek M, Jakop M, Bavec M, Bavec F. Nutrition value and use of grain amaranth: Potential future application in bread making. Agricultura. 2009 [cited 2015 sep 27];6(2):43-53. Available in: http://www.agricultura-online.com/ portal/index.php/issues/issue-10/109-nutritionvalue-and-use-of-grain-amaranth-potentialfuture-application-in-bread-making

36. Yeomans MR, Gould NJ, Mobini S, Prescott J. Acquired flavor acceptance and intake facilitated by monosodium glutamate in humans. Physiol Behav. 2008;18(93):958-66. http://dx.doi.org/10. 1016/j.physbeh.2007.12.009

37. Osorio EJ, Weisstaub NG, Castillo DC. Desarrollo de la conducta alimentaria en la infancia y sus alteraciones. Rev Chil Nutr. 2002;29(3):280-5. http://dx.doi.org/10.4067/S0717-75182002000 300002

38. Mennella JA, Trabulsi JC. Alimentos complementarios y experiencias de sabor: estableciendo las bases. Ann Nutr Metab. 2012;60(Suppl.2):40-50. http:// dx.doi.org/10.11 59/000335337

39. Pérez GRS, Vega-García LA, Romero-Juárez G. Prácticas alimentarias de mujeres rurales: ¿una nueva percepción del cuerpo? Salud Pública 
Méx. 2007 [acceso 2016 jun 25];49(1):52-62. Disponible en: http://www.scielo.org.mx/scielo. php? script=sci_arttext\&pid=S0036-3634200700 $0100008 \& \operatorname{lng}=e s \& n r m=i s o$

40. Bergel SML, Cesani MF, Oyhenart EE. Prácticas y representaciones en torno a la alimentación familiar en distintos ambientes socio-económicos (Villaguay, Argentina, 2010-2012). PSM. 2017;15(1):1-31. http://dx.doi.org/10.15517/psm. v15i1.28272

41. García BY, Muñoz GY, Urrutia OW. Grado de preferencia de galletas elaboradas en la provincial de Pamplona, Norte de Santander. Limentech. 2012 [acceso 2016 ene 20];8(2):28-33. Disponible en: http://revistas.unipamplona.edu.co/ojs_viceinves/ index.php/ALIMEN/article/view/446/445

42. Aparicio-Sanguilan A, Osorio-Díaz P, AgamaAcevedo E, Islas-Hernández JJ, Bello-Pérez
LA. Tortilla adicionada con harina de plátano inmaduro y harina de yuca: composición química y digestibilidad del almidón. CyTA J Food. 2013;11(Suppl.1):90-5. http://dx.doi.org/10.1080/194 76337.2012 .760653

43. Caselato-Sousa VM \& Amaya-Farfán J. State of knowledge on amaranth grain: A comprehensive Review. J Food Sci. 2012;77(4):93-104. http:// dx.doi.org/10.1111/j.1750-3841.2012.02645.x.

44. Algara SP, Gallegos MJ, Reyes HJ. Amaranto: efectos en la nutrición y la salud. Tlatemoani. 2013 [acceso 2015 oct 25];12:2-21. Disponible en: http://www.eumed.net/rev/tlatemoani/12/ nutricion-salud.html

Received: December 15, 2017

Final version: December 11, 2018

Approved: December 18, 2018 